\title{
WHO'S AFRAID OF THE VIENNA SALES CONVENTION (CISG)? A NEW ZEALANDER'S VIEW FROM AUSTRALIA AND JAPAN
}

\author{
Luke Nottage*
}

\begin{abstract}
Luke Nottage first sets out the structure of the CISG by reference to a New Zealand - Japan sales dispute. He prefers the CISG over traditional Anglo-Commonwealth law rules and then examines why lawyers and academics have not necessarily embraced the CISG, drawing partly on lessons from behavioural law and economics. He concludes with a call to action by those involved in the practice and study of international sales law.
\end{abstract}

\section{BACK TO THE FUTURE}

It is a pleasure to be invited back to Victoria University of Wellington (VUW) to contribute to this timely conference on international sales, law and practice. I first encountered the United Nations Convention on Contracts for the International Sale of Goods (CISG) ${ }^{1}$ as a postgraduate student at Kyoto University in the early 1990s, fresh out of VUW. The seminars in Japan led by Professor Zentaro Kitagawa also forced me to venture into other mostly unexplored territory, especially German and United States contract law theory and practice, which have played major roles in generating and advancing the Convention. Comparing Japanese law from such multiple perspectives reinforced an idea that I ended up developing beyond an LLM thesis at Kyoto University, and into a $\mathrm{PhD}$ thesis for VUW. A key argument was that the structure of legal reasoning in both Japanese and

* BCA/LLB and PhD in Law (Victoria University of Wellington (VUW)), LLM (Kyoto). Senior Lecturer, University of Sydney Faculty of Law; Co-director, Australian Network for Japanese Law ( www.law.usyd.edu.au/anjel); Director, Japanese Law Links Pty Ltd (www.japaneselawlinks.info); Visiting Associate Professor, Ritsumeikan University Law Faculty (October 2004 - January 2005). I thank Bjorn Gehle, Hiroo Sono, Koji Takahashi, and participants at the VUW International Sales Symposium, 18 February 2005 , for helpful discussions, while exempting them from all responsibility for the views and any errors presented.

1 United Nations Convention on Contracts for International Sale of Goods (April 11 1980) 1489 UNTS 3 (CISG). 
United States contract law remains much more "substantive" - directed towards "moral, economic, political, institutional, or other social consideration[s]"2 - compared to more formal reason-based English and (perhaps now especially) New Zealand contract law. This dichotomy remains despite some areas of convergence, and overlays of new sets of ("neo-procedural") norms and institutions in all four countries that share some significant parallels - but, because they involve new processes, may also play out in divergent ways. ${ }^{3}$ I am grateful for this opportunity to apply some of these ideas more specifically to cross-border contracting.

One of the more basic lessons I soon learned about the Convention in Professor Kitagawa's seminars was its usual abbreviation (and pronunciation) in Germany, "CISG" or "the CISG". That was also promptly "received" in Japan, true to its tradition of borrowing from continental Europe particularly in private law. ${ }^{4}$ But referring to the Convention as "the CISG" has also gained some following, beginning especially with American commentators, and it has often been called the "Vienna Sales Convention" in the English law tradition. ${ }^{5}$ I have used both abbreviations in my title,

2 Patrick S Atiyah and Robert S Summers Form and Substance in Anglo-American Law: A Comparative Study of Legal Reasoning, Legal Theory, and Legal Institutions (Clarendon Press, Oxford, 1987) 1.

3 Luke Nottage Form, Substance and Neo-Proceduralism in Comparative Contract Law: The Law in Books and the Law in Action in England, New Zealand, Japan and the US (PhD Thesis, Victoria University of Wellington, 2002) [Form, Substance and Neo-Proceduralism]. For earlier material related to Chapters 3 and 4, see Luke Nottage "Form and Substance in US, English, New Zealand and Japanese Law: A Framework, for Better Comparisons of Developments in the Law of Unfair Contracts" (1996) 26 VUWLR 247 and Luke Nottage "Economic Dislocation and Contract Renegotiation in New Zealand and Japan: A Preliminary Empirical Study" (1997) 27 VUWLR 59. For a concordant view recently, see for example William Whitford "A Comparison of British and American Attitudes Towards the Exercise of Judicial Discretion in Contract Law" in David Campbell, Hugh Collins and John Wightman (eds) Implicit Dimensions of Contract: Discrete, Relational and Network Contracts (Hart, Oxford, 2003) 143.

4 Zentaro Kitagawa Rezeption und Fortbildung des Europäischen Zivilrechts in Japan [Reception and Development of European Civil Law in Japan] (Alfred Metzner Verlag, Frankfurt, 1970).

5 A recent special issue of a leading German comparative law journal with material mostly in English, reflects ongoing diversity. The foreword by Reinhard Zimmermann and the cover refer to "the Convention on the International Sale of Goods", itself of course an abbreviation. From this we get "CISG", or "the CISG" as it is referred to by contributors from South Africa (Gerhard Lubbe "Fundamental Breach under the CISG: A Source of Fundamentally Divergent Results" (2004) 68 RabelsZ 55) and Italy (but with close links to Germany: Franco Ferrari "Divergences in the Application of the CISG's Rules on Non-Conformity of Goods"). An author from the Netherlands (Daan Dokter "Interpretation of Exclusion - Clauses of the Vienna Sales Convention" (2004) 68 RabelsZ 430) and another from the United States (Peter Winship "Exemptions under Article 79 of the Vienna Sales Convention" (2004) 68 RabelsZ 493) instead still refer to "the Vienna Sales Convention". However, the former uses "CISG" or "the CISG" in the body of his article, and this is three times more common in titles of articles found on the Legaltrac bibliographical database than "Vienna Sales Convention". A contemporaneous publication in Germany covers all bets: the commentary edited by Karsten Schmidt is entitled "The Vienna UN Convention on Contracts for the International Sale of Goods - CISG" (Karsten Schmidt (ed) Münchner Kommentar zum Handelsgesetzbuch Band 6: Viertes Buch. Handelsgeschäfte. Zweiter Abschnitt. Handelskauf Dritter Abschnitt. 
partly in the hope of maximising "hits" on various search engines, now this paper is being published! More importantly, I think such sensitivity to diversity within the legal harmonisation movement epitomised by this Convention is the very theme of this conference, and is crucial for both practical and theoretical reasons. Practically, compared to my friends at the United Nations Commission on International Trade Law (UNCITRAL) and some other international organisations promoting various types of instruments aimed at unifying or harmonising commercial law, I have a less direct need to emphasise the benefits and (present or future) extent of harmonisation. After all, I have already invested time and energy in studying various national systems of private law. And I would not gain so much if jurisdictions like England and Japan, for example, joined the world's other major trading nations which acceded quite quickly to CISG. So I can adopt a more "realistic" approach, which hopefully may be more persuasive to skeptics, in concluding nonetheless that they too should accede, and that other countries like Australia and New Zealand need to take measures to ensure that their accession continues to generate maximum benefits. ${ }^{6}$ Theoretically, too, acknowledging diversity within the harmonisation project is important for understanding how crossborder commercial law and practice are developing. They have increasingly involved more "soft law" measures (like Model Laws) as well as "harder" instruments (notably treaties). Both types are not exclusive, but the former have become more prominent as the scope and extent of harmonisation have grown, in an ever more complex world - also now perceived through more varied lenses. ${ }^{7}$

From that dual standpoint, this paper will focus on how countries like Japan could benefit from acceding to CISG, and how countries like Australia need to work harder to take full advantage of having acceded. In Australia - as apparently in New Zealand, according to this conference's organisers - some businesses or their legal advisers may also be excluding its operation (as permitted by article 6) when drafting cross-border sales contracts. ${ }^{8}$ This may account for quite limited case law applying CISG from those jurisdictions. This paper will reconsider the pros and cons of such a strategy, and conclude that it is generally problematic. I will assume some quite

Kommissionsgeschäft\$§ 373-406, Wiener UN-Übereinkommen über Verträge über den internationalen Warenkauf-CISG 6 ed, C H Beck Franz Vahlen, Muenchen, 2004).

6 Compare also Luke Nottage "Trade Law Harmonisation in the Asia Pacific Region: A Realist's View from New Zealand - and a Way Forward?" [1995] NZLJ 295 [Trade Law Harmonisation].

7 Luke Nottage "Legal Harmonisation" in David Clarke (ed) International Encyclopedia of Law and the Social Sciences (Sage, New York, 2006).

8 For example, a widely-read newsletter of one of Australia's largest law firms, Clayton Utz, recently included a basic (re-) introduction to CISG (see Bjorn Gehle "Export and Import: How International Law Can Make a Difference" (November 2004) Clayton Utz: International Arbitration Insights <www.claytonutz.com> (last accessed 15 June 2005). The author, a lawyer trained in Germany, explained to me that one impetus was the experience of being approached by a large Australian exporter for advice on "German sales law", even though Germany has acceded to CISG so the latter was the applicable set of norms. This indicates a disturbing ignorance still about the Convention. He also has noticed several other companies based in Australia that have expressly excluded the operation of CISG in some of their contracts. 
comprehensive overviews of CISG from the other sessions and articles in this special issue, in the best (continental) "European" tradition, represented by Professors Schlechtriem and Schwenzer. Instead, befitting my conference session dedicated to a "common law" perspective, Part II begins with a case study. It is based loosely on my experience last year helping a New Zealand company to resolve an escalating problem involving major export sales of vegetables to Japan. I will outline CISG's coherent and straightforward structure, making it easier to work through the many legal and practical issues potentially involved, at least compared to the complex body of contract and sales law in the English tradition. Overall, the key benefits of being able to apply CISG to these transactions are its accessibility, its intelligibility to business people as well as to legal professionals, and its potential for consistent interpretation (particularly if combined with dispute resolution through arbitration). Generalising even further, Part III then considers - but mostly rejects possible objections in fact broadly related to those points. One set of objections stems from traditional lawyers' preference for the familiar - and, to outsiders, the mysterious. Relatedly, especially in Anglo-Commonwealth jurisdictions, they favour more elaborated sets of norms, with their own unifying principles and supporting institutions. But the deep-rootedness of such objections suggests that certain psychological barriers, now quite well-known in other areas of law and life, may also be limiting full engagement with CISG. Part IV therefore ends by looking for ways of overcoming such biases and institutional inertia, calling for new efforts by law reformers, teachers and especially practitioners, as well as sketching some more theoretical implications.

\section{THE CASE OF THE NOT SO FLOWERY VEGETABLES}

An e-mail message makes its way through my computer's spam filters. A smaller but wellestablished New Zealand exporter of vegetables especially to Japan, whom I had helped in another Japan-related matter several years ago, needs advice on problems which have emerged in shipping quantities of another product to that country. Let's pretend it is kumara, the sweet potato some conference delegates may have enjoyed on the VUW marae the day before the conference, and known in Japan as satsuma-imo. For over a decade the client has been shipping different types of kumara to the importer, who concludes back-to-back contracts with food processing or distributor companies in Japan. This year's shipment of kumara is destined for cooking by one of these food processing companies. But a new manager at the importer is complaining that samples sent by air in advance from this year's shipment are too moist, so my client is concerned that it may reject the shipment. The client is also worried that the importer has still not taken delivery of all stock it produced for the importer last year. About 10 per cent is still sitting in the client's refrigerated warehouse, although the buyer has proposed shipment several months after the period by which it has taken delivery of all stock in previous years.

With great relief, if only because this means I will not have to dig out dusty textbooks on New Zealand contract law, I realise that CISG probably applies to the shipments agreed for last year and this year. Japan, unlike New Zealand, has not yet acceded to CISG, so the Convention is not applicable pursuant to article 1(1)(a). However, given the negotiations between the parties 
conducted in part by email and in part orally, private international law rules applied in Japan or in New Zealand would likely lead to the application of the contract law of New Zealand, so CISG would apply pursuant to article 1(1)(b). ${ }^{9}$ Each year's agreed shipment is a sale of goods by instalments, covered by article 2, as opposed to some sort of framework or distributorship contract. ${ }^{10}$ Sales of future goods, to be produced for the importer by the client later contracting with New Zealand growers each year, are envisaged by article 3(1). Thus, a quick look through Part I Chapter I of the Convention (Sphere of Application) confirms that it is probably applicable.

Part I Chapter II then adds some "General Provisions" relevant to both contract formation and breach issues raised by this case. Article 8 establishes clear and sensible rules for interpreting statements or conduct relating to contract formation or breach. For example, if the importer had made statements about its requirements for this year's kumara, these should be interpreted according to its subjective intent, but only if the client "knew or could not have been unaware what that intent was". ${ }^{11}$ Since that situation is unlikely, or at least difficult to prove, usually the statements will be interpreted objectively, "according to the understanding that a reasonable person of the same kind as the [client] would have had", ${ }^{12}$ considering circumstances such as the negotiations, practices established by the parties, usages, and any subsequent conduct of the parties. ${ }^{13}$ Article $9(1)$ adds that parties are bound by any usages or practices they have established among themselves, a particularly likely scenario in long-term business relationships like this case study. ${ }^{14}$ Article $9(2)$ goes further in

9 Very few countries have made a reservation excluding article 1(1)(b) pursuant to article 95 . The most significant is the United States.

10 Compare for example John Honnold Uniform Law for International Sales under the 1980 United Nations Convention (Kluwer Law International, The Hague, 1999) para 56.2; and Downs Investments Pty Ltd v Perwaja Steel SDN BHD [2001] QCA 433.

11 CISG, above n 1, part 1 ch II act 8(1). David McLauchlan has long campaigned to have New Zealand courts leave some scope for subjective interpretation of contracts, see: David McLauchlan "Actual Consensus Ad Idem: Unneccessary but Surely Sufficient?" [1995] NZLJ 436. However, he may not be prepared to go as far as CISG.

12 CISG, above n 1, art 8(2).

13 CISG, above n 1, art 8(3). David McLauchlan has also been scathing of New Zealand courts' exclusion of subsequent conduct in interpreting contracts, see: David McLauchlan "Subsequent Conduct and Contract Interpretation: An Update" (1997) 3 NZBLQ 147. Further, the broad interpretive scheme established by CISG article 8 makes it much more difficult to apply a "parol evidence rule" (Honnold, above n 10, para 121). That is undermined anyway by a raft of exceptions or limitations under Anglo-American common law nowadays, see: for example Lindy Willmott, and others Contract Law (Oxford University Press, Melbourne, 2001) 233-7.

14 Again, however, courts particularly in the English law tradition have had trouble acknowledging this sort of reality. See for example Jane Swanton "Incorporation of Contractual Terms by a Course of Dealing" (1980) 1 JCL 223; Stephen Kapnoullas "Prior Dealings and the 'Reasonable Objective Expectation' of Contracting Parties" (1996) 10 JCL 173. Compare generally Clayton Gillette "The Law Merchant in the Modern Age: Institutional Design and International Usages under the CISG" (2004) 5 Chi J Int'l L 157. 
making applicable a "usage of which the parties knew or ought to have known and which in international trade is widely known to, and regularly observed by, parties to contracts of the type involved in the particular trade concerned". Article 11 emphasises that sales under CISG need not be concluded in or evidenced by writing, and are not subject to any requirements as to form. ${ }^{15}$ Evidence that this conforms to widespread commercial expectations is provided by the few instances where this article has been subject to a reservation under article 96. Article 7(1) reinforces this orientation by demanding interpretation of CISG in the light of its "international character" and "the need to promote uniformity in its application", as well as "the observance of good faith in international trade". The latter requirement, or the requirement to fill gaps in CISG "in conformity with its general principles" (such as, arguably, "reasonableness") or otherwise the applicable domestic law, has led especially German and some United States commentators to conclude that CISG in effect imposes a general duty of good faith on parties themselves. ${ }^{16}$

These general rules make it significantly more likely that a contract will be found to be formed, an area of law covered by Part II of the Convention, and a crucial first hurdle for my client in this case. Particularly important in the context of more informal dealings, offers must be "sufficiently definite" - indicating the goods, and expressly or impliedly determining both quantity and price - as well as revealing the offeror's intention to be bound upon acceptance. ${ }^{17}$ But courts and arbitral tribunals have taken quite an expansive approach to the definiteness requirement. ${ }^{18}$ Article 65 may also assist, by allowing the seller to make specifications of the goods if the buyer fails to do so as agreed. In my client's case, however, basic agreement on prices, quantities, and the goods generally was reached primarily by email correspondence, with sufficient further detail provided already by their regular pattern of dealings, later amplified by exchanging detailed specification sheets. More generally, CISG's readiness to uphold contract formation is evidenced by the irrevocability of "firm

15 Compare the line of cases especially in New Zealand law suggesting that there is a "presumption" (as opposed to a factual inference) that certain complex commercial transactions negotiated through lawyers and agreed "subject to contract", or the like, are not intended immediately to create binding contractual obligations. See Concorde v Anthony Motors (Hutt) Ltd [1981] 2 NZLR 385 (CA) (a cross-border distributorship), and the extensive comparisons in Form, Substance and Neo-Proceduralism, above n 3, ch 2.

16 Honnold, above n 10, especially paras 94-5 (referring also for example to Professor Schlechtriem); and case law summarised in the UNCITRAL Digest, UNCITRAL <http://www.uncitral.org > (last accessed 18 June 2005) art 7 paras 8-10.

17 CISG, above n 1, art 14(1).

18 This is true even in France, where domestic sales law (understood as applicable via article 55) has traditionally required agreement on price. See Fauba $v$ Fujitsu Pace Law School CISG Database $<$ http://www.cisg.law.pace.edu $>$ (last accessed 18 June 2005). More generally on New Zealand law, compare David McLauchlan "Intention, Incompleteness and Uncertainty in the New Zealand Court of Appeal" (2002) 18 JCL 153. 
offers" ${ }^{19}$ widely used by business people even though the English law tradition insists they are as irrevocable as any other offers. ${ }^{20}$ Another indication is some relaxation of its strict "mirror image rule", requiring the acceptance to match the offer perfectly. ${ }^{21}$

Part III of CISG (Sale of Goods) then sets out the duties of buyers and sellers, and what happens if there is a disturbance to the normal course of performance - especially a breach. Chapter I (General Provisions) hints already at two main remedies. The innocent party can demand the promised performance, unless a local court (usually in the breaching party's home state) would not enforce specific performance under domestic law for similar sales not governed by CISG. ${ }^{22}$ The proviso was a compromise urged by common law jurisdictions, traditionally viewing specific performance as an exceptional remedy, but the threat to uniformity is reduced by considerable convergence on the approach adopted by civil law jurisdictions. At least, situations where differences remain are quite easy to identify. ${ }^{23}$ Thus, where for example specific performance would not readily be granted in a domestic context, the innocent party can instead notify the breaching party that it is "avoiding" or terminating the contract, ${ }^{24}$ if the breach is "fundamental" or serious

19 CISG, above n 1, art 16(2)

20 Compare the United States Uniform Commercial Code (UCC), arts 204-205, and Richard Lewis "Contracts Between Businessmen: Reform of the Law of Firm Offers and an Empirical Study of Tendering Practices in the Building Industry" (1982) 9 British Journal of Law \& Society 153.

21 CISG, above n 1, art 19. Compare generally Arthur von Mehren "The 'Battle of the Forms': A Comparative View" (1990) 38 Am J Comp L 265. The compromise expressed in article 19(3) still appears quite strict, compared especially to the UCC (article 2-207) or UNIDROIT Principles of International Commercial Contracts (2004) (UPICC) <www.unidroit.org> (last accessed 18 June 2005); on possibilities to use them to amplify CISG, see for example Seig Eiselen "Remarks on the Manner in Which the UNIDROIT Principles of International Contracts May Be Used to Interpret or Supplement Article 29 of the CISG" (2002) Pace Int'l LJ 14. But the "offer" referred to can itself be interpreted quite broadly, thanks to CISG articles 8 and 9 , meaning less scope for conflict between it and the reply. Some commentators, including Professor Schlechtriem, go even further in the direction of a 2002 judgment of the German Federal Supreme Court BGH, 9 January 2002 CISG-online no 651 <www.cisg-online.ch> (last accessed 19 July 2005) and advocate implied exclusion of article 19's prima facie "last shot" rule, substituting the "knock out" rule: Dokter, above n 5, 439-440. This really stretches the wording and legislative history of CISG, but would tend to uphold more contracts.

CISG is more obviously less favourable towards contract formation, compared to the English law tradition, by not allowing for a "postal acceptance rule" (compare article 15(1)). But that is an odd rule anyway, generated by peculiar historical circumstances: see Simon Gardner "Trashing with Trollope: A Deconstruction of the Postal Rules in Contract" (1992) 12 OJLS 170.

22 CISG, above n 1 , art 28.

23 See generally Gunther Treitel Remedies for Breach of Contract: A Comparative Account (Clarendon Press, Oxford, 1988).

24 CISG, above n 1, art 27. 
enough. ${ }^{25}$ The test for the latter is quite complex, as mentioned below; but it has not led to as much divergence in case law as some expected ${ }^{26}$ and parties should tailor their contracts to provide more guidance if needed.

Chapter II of Part III then sets out in more detail the "Obligations of the Seller", followed by the buyer's remedies for breach. In our case, the client should deliver last year's supply of kumara within the period set by the contract (as supplemented by the regular pattern of dealings with the Japanese importer), or otherwise within a reasonable period after conclusion of that instalment sale. ${ }^{27}$ This year's supply must also conform with any new standards agreed in the initial agreement and the specification sheets, ${ }^{28}$ and otherwise meet standards similar to implied terms under Anglo-New Zealand-Australian sales of goods legislation, ${ }^{29}$ unless the buyer knew or could not have been unaware of non-conformity when contracting. ${ }^{30}$ Innocent misrepresentations as to quality of the goods, up until and including the time of contract formation, should be subjected to the same standards and remedies for breach, pursuant to the gap-filling mandate of article $7(2) .{ }^{31}$ This avoids having to revert to the mysterious distinction between misrepresentations and contractual warranties - with even more complicated implications as to remedies for breach - found especially in AngloAustralian law. ${ }^{32}$ On the other hand, subject to liability for any damages nonetheless incurred by the buyer, the seller can cure any non-conformity up until the time agreed for performance, ${ }^{33}$ and even afterwards, if not unreasonable for the buyer. ${ }^{34}$ The buyer must also promptly examine the goods, ${ }^{35}$ and the buyer loses the right to reply on non-conformity by failing to notify the seller thereof within a reasonable time after the buyer discovered it or ought to have done so. ${ }^{36}$ Article 39(1) has been Contractual Remedies Act 1979 also thankfully take much of the bite out of the distinction by conflating remedies for mispresentations with those for breach of contractual promises. However, the Act has generated its own complexities. See generally John F Burrows, Jeremy Finn and Stephen Todd Law of Contract in New Zealand (LexisNexis, Wellington, 2002).

33 CISG, above n 1, art 37

34

35

CISG, above n 1, art 25.

Lubbe, above n 5, 444-461.

CISG, above n 1, art 33(b) and (c).

CISG, above n 1, art 35(1).

CISG, above n 1, art 35(2).

CISG, above n 1, art 35(3).

Honnold, above n 10, para 102.

CISG, above n 1, art 48 .

CISG, above n 1, art 38

CISG, above n 1, art 39, subject to art 44 . 
one of CISG's most heavily litigated provisions, so parties should try to add more specific time limits to their contracts. ${ }^{37}$

If the client exporter remains in actionable breach of this year's supply contract, by supplying non-conforming goods, the Japanese buyer may require performance, getting the exporter to repair the non-conformity, ${ }^{38}$ or to supply substitute goods for the non-conforming ones if those amount to a fundamental breach. ${ }^{39}$ However, if only to salvage business reputation, exporters usually want to rectify non-conformity anyway. ${ }^{40}$ Further, even without problems of enforcing such remedies through local courts, an importer may be prevented from pursuing them if this would be contrary to the good faith principle arguably underlying CISG (for example by delaying the required notification, to speculate on market movements at the expense of the exporter) ${ }^{41}$ Another limit to claiming performance arises if the importer has resorted to an inconsistent remedy, ${ }^{42}$ namely avoidance or termination - designed instead to break off primary obligations between the parties. ${ }^{43}$ Many more cases have been decided under CISG regarding this remedy of avoidance. Uncertainty as to whether the importer can invoke the remedy can be lessened if the exporter fails to deliver at all. The importer can specify an additional reasonable period for performance, ${ }^{44}$ and then safely avoid the contract if performance is not forthcoming or is refused. ${ }^{45}$ Otherwise, the importer has to be able to establish a fundamental breach. ${ }^{46}$ This hurdle focuses on whether the innocent party actually suffered a detriment substantially depriving it of what it expected under the contract, ${ }^{47}$ and

37 Ferrari, above n 5, 485-491.

38 CISG, above n 1, art 46(3).

39 CISG, above n 1, art 46(2).

40 Honnold, above n 10, para 286.

41 Honnold, above n 10, para 285. See also Koji Takahashi "Right to Terminate (Avoid) International Sales of Commodities" [2003] JBL 102, comparing English and CISG approaches to such "attempts at unmeritorious termination". Compare also the more detailed factors provided in UNIDROIT Principles of International Commercial Contracts (2004) (UPICC) <www.unidroit.org> (last accessed 18 June 2005) art 7.2.2 as to whether or not specific performance should be permitted for a non-monetary obligation. A further limit to the buyer's right to avoidance (or, indeed, to require substitute goods) is found in CISG article 82(1), namely the requirement of restitio in integrum. However, it is hemmed in by article 82(2), and the buyer retains all other remedies pursuant to article 83 .

42 CISG, above n 1, art 46(1).

43 CISG, above n 1, art 49.

44 CISG, above n 1, art 47.

45 CISG, above n 1, art 49(1)(b).

46 CISG, above n 1, art 49(1)(a).

47 CISG, above n 1, art 25. 
is set somewhat higher than in more complex Anglo-Australian sales law. ${ }^{48}$ One longstanding reason for more caution about recognising a fundamental breach, thus allowing avoidance, is that waste tends to result from reshipment or redisposition after cross-border shipment. There are also concerns about allowing speculation or benefits from market shifts at the expense of the breaching party. ${ }^{49}$ Consistently with this approach, article 51 clarifies that even a serious non-conformity afflicting a portion of the supply only allows avoidance or rejection of that portion, ${ }^{50}$ unless that breach was fundamental to the entire contract. ${ }^{51}$ Likewise, and importantly for the client's supply of kumara planned for this year, article 73 adds detailed requirements as to when a defective instalment can allow avoidance of the entire instalment sale contract.

Chapter III of Part III sets out, in parallel, the "Obligations of the Buyer" and seller's corresponding remedies for breach. The importer must take delivery of the goods and pay for them, as required by the contract and $\mathrm{CISG},{ }^{52}$ including taking reasonable steps to enable the exporter to make the delivery. ${ }^{53}$ The client exporter can refer to their negotiations and agreement for the timely delivery of last year's supply kumara, amplified by the parties' pattern of dealing, but also the commercial unreasonableness of having to store the remaining stock beyond the usual period. Further, if the importer wrongly declares rejection of this year's supply before the agreed times or period for deliveries, the exporter can immediately treat this refusal to pay as a ground for suspending its own performance, giving the importer another chance to provide adequate assurance of performance. ${ }^{54}$ This very useful remedy remains unknown to Anglo-Australian-New Zealand sales law. ${ }^{55}$ If the exporter is confident that the rejection is baseless, it can even avoid for "anticipatory breach" of the instalment sale for this year's kumara. ${ }^{56}$ Avoidance is also allowed if other circumstances make it clear that the importer will commit a fundamental breach, but only (if

48 English law has developed a similar concept of "intermediate term", but the first step is to determine whether the parties intended that, or instead a "condition" (allowing termination even for the slightest breach, and presumed for example regarding time stipulations in commercial contracts) or a "warranty" (allowing only damages). See Willmott and others, above n 13, 288-295; Takahashi, above n 41.

50 CISG, above n 1 , art 51 para 1.

51 CISG, above n 1 , art 51 para 2.

52 CISG, above n 1, art 53.

53 CISG, above n 1, art 60.

54 CISG, above n 1, art 71.

55 This is one of several improvements that Roy Goode believes can be borrowed from CISG. He also criticises English law's persistent reluctance to countenance agreements to negotiate, assurance of performance following anticipatory breach, and excuses for frustration: see Roy Goode Commercial Law in the Next Millennium (Sweet \& Maxwell, London, 1998) 32-38.

56 CISG, above n 1, art 72(3). 
time allows) after giving reasonable notice again allowing the importer to provide adequate assurance of performance. ${ }^{57}$ Alternatively, the exporter can wait until the agreed times or period for deliveries have expired, then avoid the contract either directly for fundamental breach, ${ }^{58}$ or after setting a further reasonable period (under article 63) for the importer to take delivery and pay the contract $_{\text {price. }}{ }^{59}$

Chapter IV then deals with "Passing of Risk". For example, article 69(1) clarifies that generally the risk passes to the buyer either upon taking over the goods, or (as is likely applicable both for the undelivered shipment last year and for this year's supply of kumara) from when the goods are placed at the buyer's disposal but the latter commits a breach of contract by failing to take delivery. Chapter V adds "Provisions Common to the Obligations of the Seller and of the Buyer". Those relating to anticipatory breach and instalment sales have been already noted. ${ }^{60}$ Articles $74-77$ set the measures for damages, available if loss is suffered by either the buyer ${ }^{61}$ or seller, ${ }^{62}$ with or without having exercised other remedies such as avoidance of the contract. Damages can be reduced if the innocent party fails to mitigate the loss. ${ }^{63}$ Article 74 on remoteness basically restates the old English case of Hadley $v$ Baxendale, which drew on French legal writing and in turn influenced Japanese law. ${ }^{64}$ One related problem is clarified by article 78: a party (like the importer here) that fails to pay the contract price or any other sum in arrears is further liable for interest on it. However, no consensus could be reached on specifying the rate of interest, ${ }^{65}$ generating a considerable number of cases and the need for additional contract drafting on this matter. Article 84(1), found in a later section on "Effects of Avoidance", also mentions that if the seller then refunds the contract price received, it must also pay interest on it from the date when the price was paid. Such refunds, or restitution for

57 CISG, above n 1, arts 72(1) and (2). As pointed out by Lubbe, above n 5, 463-465, the nuances of these rules comprise one area where Australian courts need to note some significant differences with domestic contract law: South Sydney District Rugby League Football Club Ltd v News Ltd [2001] FCA 862; Downs Investments $v$ Perwaja Steel [2000] QSC 421, for example on repudiation as opposed to future inability to perform.

58 CISG, above n 1, art 64(1)(a).

59 CISG, above n 1, art 64(1)(b). As Jacob Ziegel noted too in criticising the Roder Zelt judgment (Roder ZeltUnd Hallenkonstruktionen GMBH v Rosedown Park Pty Ltd 57 FCR 216), the article 63(1) Nachfrist is not obligatory: Lubbe, above n 5, 455.

60 CISG, above n 1, arts 71-73.

61 CISG, above n 1, art 45(1)(b).

62 CISG, above n 1, art 61(1)(b).

63 CISG, above n 1, art 77.

64 Hadley $v$ Baxendale (1954) 9 Exch 341. See Kitagawa, above n 4.

65 Compare UPICC < www.unidroit.org > (last accessed 18 June 2005) art 7.4.9. See generally Florian Faust "Zinsen Bei Zahlungsverzug [Interest on Delayed Payments]" (2004) 68 RabelsZ 473. 
supplies, are required under article 81, which also clarifies that contract avoidance releases the parties from their future obligations. The next section, in articles $85-88$, adds specific and sensible rules on preserving goods after a dispute arises, not limited to situations involving fundamental breach or avoidance of the contract.

A remaining section in Chapter V of Part III contains a set of provisions on "Exemptions", dealing with impediments to performance due to changed circumstances that do not amount to a breach of contract. Particularly important is article 79, which one primary architect of CISG acknowledges "may be the Convention's least successful part of the half-century of work towards international uniformity", calling therefore also for careful additional contract drafting. ${ }^{66}$ However, the framework established seems a distinct improvement on the English common law of frustration. Rather similarly to that, article 79(1) excuses a party if it can prove that failure to perform was due to an "impediment beyond his control" that he could not "reasonably be expected to have taken ... into account" at contract formation or "to have avoided or overcome it or its consequences". However, contrary to Anglo-New Zealand law, it seems that pure commercial impracticability due to extreme market or price level fluctuations may amount to such an impediment - but only in truly exceptional circumstances. ${ }^{67}$ Further, the "reasonableness" standard required to overcome consequences of an impediment, potentially combined with the good faith principle derived through article 7 , gives more flexibility to provide relief compared to the strict requirement that frustration not be (even slightly) "self-induced", maintained especially by English courts. ${ }^{68}$ Somewhat more scope to allow an excuse also fits well with less extreme consequences that follow under article 79(3) through (5). Unlike the English law tradition, the contract does not come automatically to an end. The impeded party is simply excused from damages for the duration of the impediment, unless the other party finds that this becomes as serious as a normal contract breach that would give rise to a right to avoid the contract. In all these respects, the framework is much closer to United States and Japanese law. ${ }^{69}$ Like the requirement that the impeded party promptly notify the other of the impediment and its impact, this reinforces CISG's orientation towards keeping the contract alive. In

66 Honnold, above n 10, para 432.1.

67 Honnold, above n 10, para 432.2. Professor Honnold agrees with an early view of Professor Schlechtriem that article 79 should be extended - in theory - to these situations, to prevent courts finding a gap in CISG and then (pursuant to article 7(2)) applying divergent domestic law. This view has largely been followed in CISG decisions, especially in Western Europe: see Peter Winship "Exemptions under Article 79 of the Vienna Sales Convention" (2004) 68 RabelsZ 493, 507-510. See also the UNCITRAL "Digest of Case Law on the United Nations Convention on the International Sale of Goods" <www.uncitral.org $>$ (last accessed 19 June 2005) A/CN.9/SER.C/DIGEST/CISG/79.

68 The Super Servant Two [1990] 1 Lloyd's Rep 1 (CA).

69 Form, Substance and Neo-Proceduralism, above n 3, ch 4. A significant - or at least symbolic - difference is that there is no possibility whatsoever of court adjustment of the parties' obligations. Compare for example UPICC, above n 41, arts 7.1.7, 6.2.1-6.2.3. 
my client's case, this creates an obligation on the Japanese buyer to notify any possible extraneous reasons for not wanting to continue importing this year's kumara supply. Article 79 also means little likelihood that problems with its own customers or general market conditions will be sufficient to provide an excuse, but more chance of salvaging the contract (and the business relationship) if indeed there has been drastic economic dislocation.

Thus, CISG offers a logical, coherent and comprehensive framework for working through quite complex legal issues that can develop in negotiating and implementing cross-border sales. One key advantage is therefore the accessibility of the Convention. Recent empirical research in Australia suggests considerable benefits, even for people with some legal training active in common law jurisdictions, from succinct statements of contract law through codification techniques, rather than the verbose case law (and accretions of statute law) that commentators try endlessly to summarise, rationalise or criticise. ${ }^{70}$ The layout of CISG is also logical, generally tracking the issues as they arise in actual commercial transactions.

It can also be reassuring for clients, less willing to put blind trust in lawyers nowadays, to be able to double-check basics about the Convention. The provisions can be easily viewed on the UNCITRAL website, along with a concise and authoritative introduction by the Secretariat. Its "Case Law on UNCITRAL Texts" (CLOUT) service provides abstracts of over 1000 cases applying CISG world-wide, supplemented since mid-2004 by an extremely helpful "Digest" of the cases for each article of the Convention. ${ }^{71}$ Few practitioners will need to look much further than this website, especially if just seeking to access the Convention for guidance in planning transactions rather than resolving a specific dispute. But in addition, the Pace University website covers even more cases, reproducing many in full text and a growing number in full or partial translation, as well as important secondary literature and links to CISG websites maintained by other academics in over a dozen countries (including Australia and Japan). ${ }^{72}$ Most responsible practitioners, and even contract law scholars, need only supplement this wealth of accessible online material with one of several very authoritative textbooks now readily available. ${ }^{73}$

70 Fred Ellingham and Edward Wright with Maria Karras Models of Contract Law: An Empirical Evaluation of their Utility (Themis Press, Sydney, 2005).

71 The Digest informed presentations and discussions at the Joint Conference, "Celebrating Success", hosted by UNCITRAL and the Vienna International Arbitral Centre (VIAC) in Vienna over 15-18 March 2005. The first two days, "From the 1980 Vienna Conference to the Digest and Beyond: Cases, Analysis and Unresolved Issues in the CISG", largely presented topics following sets of articles in CISG.

72 See, respectively, UNCITRAL < www.uncitral.org > (last accessed 15 June 2005); and Pace Law School CISG Database <http://www.cisg.law.pace.edu> (last accessed 18 June 2005).

73 My preference is for Honnold, above n 10, partly because of his common law background but also because it is in soft cover and therefore cheaper! But the hard-cover textbook edited by Peter Schlechtriem and Ingeborg Schwenzer (eds) Commentary on the UN Convention on the International Sale of Goods (CISG) (2 ed, Clarendon Press; Oxford, New York, 2005) is an excellent substitute, especially for academics. A strong 
Another advantage is CISG's intelligibility in a broader sense. Its guiding principles seem to accord better with commercial expectations than mainstream sales law in the English tradition. For example, even in the United Kingdom, it has long been observed that businesspeople care little for the legal niceties of contract formation. They prefer to stand by their contracts, and maintain their own ways of negotiating and managing contracts, even when lawyers or law professors point out that some strict rules of domestic law may mean that their agreements are not enforceable. ${ }^{74}$ This would also likely be true in the situation facing my client. Even the Japanese importer would be unlikely to claim that this year's kumara supply contract was not validly formed, although that would mean that it did not need to accept the goods. A legal adviser suggesting this strategy, at least at an early stage of the dispute, would probably be seen in a skeptical light - lacking (business) common sense, probably jeopardising any chance of salvaging the relationship, and even becoming too much of a "hired gun". While pursuing their clients' interests, effective legal advisers must remain conscious that the law often develops a normative structure and content differing from everyday common sense, engendering discomfort when divergence becomes too extreme yet the law is pressed into service to supplant that common sense. ${ }^{75}$

Less divergence is apparent regarding quality problems. Abiding by promised standards is expected. ${ }^{76}$ But there may be disagreement about the applicable standard, especially a tension between written and unwritten standards. ${ }^{77}$ The law may give more deference to the former than even the most sophisticated commercial parties would normally expect. The unwritten standards can also more readily incorporate the rules and practices of particular trades, including sometimes overlapping communities of international businesspeople and their associations. ${ }^{78}$ Even if the

new contender should be Peter Schlechtriem and Petra Butler UN Law on International Sales (Springer, forthcoming).

74 Hugh Beale and Tony Dugdale "Contracts between Businessmen: Planning and the Use of Contractual Remedies" (1975) British Journal of Law \& Society 45; Stewart Macaulay "Non-Contractual Relations in Business: A Preliminary Study" (1963) 28 American Sociological Review 55. See also Luke Nottage "Planning and Renegotiating Long-Term Contracts in New Zealand and Japan: An Interim Report on an Empirical Research Project" [1997] NZ L Rev 482.

75 See Takao Tanase (Luke Nottage and Leon Wolff, trans) The Hermeneutics of Japanese Law: Community and Modernity (manuscript forthcoming), especially the chapter on Lawyers' Ethics. Compare also Hugh Collins "Introduction: The Research Agenda of Implicit Dimensions of Contracts" in David Campbell, Hugh Collins and John Wightman Implicit Dimensions of Contract: Discrete, Relational and Network Contracts (Hart, Oxford, 2003) 10.

76 Nottage, above n 74. See also Stewart Macaulay "The Real and the Paper Deal: Empirical Pictures of Relationships, Complexity and the Urge for Simple Transparent Rules" in David Campbell, Hugh Collins and Wightman, above n 75, 89-98.

77 See generally for example Macaulay, above $\mathrm{n} 76$.

78 See John Wightman "Beyond Custom: Contract, Contexts, and the Recognition of Implicit Understandings" in Campbell, Collins and Wightman (eds), above n 75, 143; Filip DeLy "Uniform Commercial Law and 
standards are agreed, the consequences of not meeting them may be less exacting than the law demands. Suppliers are not necessarily required - in practice, if not on paper - to bear all consequential losses upon breaching quality specifications. Instead, they tend to get away with repair or replacement. ${ }^{79}$ This tends to maintain the contractual and the business relationships. Similarly, termination rights are often restricted or not exercised. ${ }^{80}$ Also, even in New Zealand, firms do not exhibit the same adamant rejection of court adjustment of ongoing obligations that is demanded by Anglo-New Zealand contract law. Likewise, they are more prepared to allow some excuse even for extreme commercial impracticability. ${ }^{81}$

Thus, by more readily upholding contract formation than in the English law tradition, and then being cautious about allowing termination unless all hope is lost for the relationship, CISG seems to mesh better with the expectations and practices of traders world-wide. Reinforcing both aspects is the possibility - although still not the certitude - of bringing in a general duty of good faith via article 7. At least when negotiating an agreement or resolving out of court an unfolding dispute like my client's, that more readily allows the client and/or the legal adviser to present arguments framed in the language of good faith or reasonableness. Businesspeople on the other side can choose to interpret those in a commercial sense, but their legal advisers should realise that there are also legal connotations, either directly or via other more specific rules of sales law.

If the dispute does come before a court, and especially if it comes before an arbitral tribunal, CISG offers much more chance of consistency in interpretation. Sales law in the English tradition may also be more predictable in some areas, but only to the initiated. There may also be less guarantee of getting that domestic law applied. Even if the laws determining the governing law are clear, more arguments may emerge about jurisdiction, as each side tries to achieve a tactical advantage in court or arbitral proceedings. Certainly, the costs of applying one domestic sales law are going to be considerably higher for one party, compared to applying a neutral set of rules like CISG.

Finally, these general advantages of accessibility, intelligibility and consistency extend beyond dispute resolution processes. CISG also can benefit businesspeople and their legal advisers when they are negotiating and drafting sales (and, indeed, other commercial agreements). Familiarity with

International Self-Regulation" in Franco Ferrari (ed) The Unification of International Commercial Law (Nomos, Baden-Baden, 1998) 59.

79 Macaulay, above n 76.

80 Jacob Ziegel "Commentary on 'Party Autonomy and Statutory Regulation: Sale of Goods"' (1993) 6 JCL 123.

81 Nottage, above n 74. See also Macaulay, above n 76 89-98. 
its rules can provide more meaningful and generalisable checklists and guidance on matters to be addressed and negotiated when planning cross-border deals. ${ }^{82}$

\section{III "DON'T BE A CIS $(G) Y "$ ?}

What are some even broader lessons to draw from this case study? A conventional view, as propounded by officials from UNCITRAL and other organisations involved in promoting instruments like CISG, would summarise many of the identified advantages as involving reductions in transaction costs through legal harmonisation. ${ }^{83}$ That benefit is probably very real, but it is difficult to quantify. This is problematic, especially if combined with an observed tendency for individuals to highlight certain risks or costs but to ignore or underestimate benefits, ${ }^{84}$ because a cost-benefit analysis will then tend to conclude that CISG should not be adopted or applied. Further, to more directly confront skeptics, it may be more persuasive for me to begin by analysing possible flip sides to the three specific advantages just identified in using CISG to resolve problems raised by the likes of my case study.

First, although greater accessibility seems unimpeachable, a problem for lawyers is that they prefer the familiar. In this case, it means good old New Zealand or Japanese sales law, including precedent contracts or clauses drafted from that basis which lurk in a firm's computers or other clients' box files. It is not just that lawyers love precedents. After all, that can encourage "legal transplants" or borrowing even from abroad. ${ }^{85}$ A more specific reason for their preference for the familiar, of course, is that practitioners have sunk costs in that pre-existing stock of knowledge. Investing in new knowledge about CISG and updating precedents may seem to involve too much pain for too little direct gain. The problem may be compounded for small law firms, which probably still engage the bulk of practitioners in New Zealand, Japan and Australia. ${ }^{86}$ But this dilemma tends to be overcome in other areas of legal practice, for example through cost-effective Continuing Legal Education seminars (especially those run by the New Zealand Law Society). A good example is the legal profession's gradual self-education about, and adoption of, alternative dispute resolution

82 Compare for example Klaus Peter Berger (ed) The Practice of Transnational Law (Kluwer Law International, The Hague; London, 2001). His empirical study confirmed a significant role even for the general lex mercatoria at this stage, as well as during dispute resolution.

83 See also Dominik Kallweit "Towards a European Contract Law" (2004) 9 Yearbook of the New Zealand Association of Comparative Law 269.

84 Compare Cass R Sunstein Risk and Reason: Safety, Law, and the Environment (Cambridge University Press, Cambridge; New York, 2002) 40-43.

85 See generally William Ewald "Comparative Jurisprudence (II): The Logic of Legal Transplants" (1995) 43 Am J Comp L 489.

86 Richard L Abel and Philip Simon Coleman Lewis (eds) The Common Law World (University of California Press, Berkeley, 1988); Richard L Abel English Lawyers between Market and State - The Politics of Professionalism (Oxford University Press, Oxford, 2003). 
processes. Initially, most lawyers in New Zealand and Australia may have seen "ADR" as standing for "Always Declining Revenue"! But now they tend to practice at least some ADR techniques. ${ }^{87}$ Another example is a move away from "reactive" dispute resolution altogether, towards more proactive dispute prevention. ${ }^{88}$ When this draws on advances and new skills in information technology (IT), it indicates also a broader transformation in legal services markets, towards "legal information engineering". ${ }^{89}$ A third example comes from further afield, from an antipodean perspective: the uptake of European Union (EU) law by English lawyers. Even the large, internationally-oriented law firms seemed slow off the mark, compared for example to German firms; but they have caught up, generally and in specialised areas. ${ }^{90}$ Thus, strategically, updating knowledge and skills can readily make for longer-term profit. Further, more defensively, lawyers nowadays must be more conscious about potential claims of professional negligence. ${ }^{91}$ So if they persist in sticking to what they know and love, namely national sales law and precedents, other factors probably account for not taking up CISG.

87 See generally Peter Spiller (ed) Dispute Resolution in New Zealand (Oxford University Press, Auckland, 1999); Hilary Astor and Christine Chinkin Dispute Resolution in Australia (Butterworths, Sydney, 2002). Compare the situation in Japan, where court-annexed mediation and government-supported ADR schemes have been popular, but commercially provided ADR has been comparatively weak: Luke Nottage and Leon Wolff "Japan" in Doing Business in Asia (loose leaf, CCH Pte Ltd, Singapore) (last updated 2005); Gerald McAlinn and Luke Nottage "Changing the (JCAA) Rules: Improving International Commercial Arbitration in Japan" (2005) 18 J Japan L 23.

88 See for example Ryo Hamano "Japanese Lawyers in Transition" (1998) 49 Rikkyo Hogaku 325. In the cross-border context, see for example Martin Hunter "International Commercial Dispute Resolution: The Challenge of the Twenty-First Century" (2000) 16 Arbitration International 379.

89 Luke Nottage "Cyberspace and the Future of Law, Legal Education and Practice in Japan" (1998) 5 Web Journal of Current Legal Issues <http://webjcl.ac.uk> (last accessed 15 June 2005); Richard E Susskind Transforming the Law: Essays on Technology, Justice, and the Legal Marketplace (Oxford University Press, Oxford, 2000); Makoto Ibusuki and Luke Nottage "IT and Legal Practice and Education in Japan and Australia" (2002) 4 UTS L Rev 31; Makoto Ibusuki "Hojohokankyo No Henyo to Bengoshi No Yakuwari [Lawyers' Roles and Transformations in the Legal Information Environment]" (2004) 10 Jiyu to Seigi 36.

90 An example of a EU law specialisation is Lovells' practice in product liability (referred to in Luke Nottage Product Safety and Liability Law in Japan: From Minimata to Mad Cows (RoutledgeCurzon, London, 2004). Another, apparently, is the work of English international law firms with a presence in Tokyo (for example Clifford Chance "Clifford Chance comes out a Winner in Asian Private Equity" $<$ http://www.cliffordchance.com> (last accessed 15 June 2005), through joint ventures (for example Clifford Chance Tanaka Akita \& Nakagawa) and no doubt when full partnerships can commence there from April 2005 (for example Freshfields, <http://www.freshfields.com> (last accessed 15 June 2005)). Compare Yasuharu Nagashima and Anthony Zaloom "The Rise of the Large Japanese Business Law Firm and its Prospects for the Future" (Conference on "Law in Japan: A Turning Point", University of Washington, 2324 August 2002).

91 See generally Gino Dal Pont Lawyers' Professional Responsibility in Australia and New Zealand (LBC Information Services, Pyrmont, 2001); Takeshi Kawai and Tsutomu Shiozaki Senmonka Sekinin Soshoho [Legal Issues in Litigation Involving Professional Liability] (Seirin Shoin, Tokyo, 2004). 
Lessons from social psychology, increasingly applied to a range of legal phenomena in recent years, can begin to explain this puzzle. A rich vein of empirical and theoretical literature has shown how decision-making - especially by laypeople, but also many attempts at cost-benefit analysis by experts - can be tainted by various "heuristics". Such short-cuts may be quite effective rules of thumb for everyday life, but they become more and more problematic when applied to increasingly complex situations. One is the "availability heuristic", whereby "people tend to think that events are more probable if they can recall an incident of their occurrence". ${ }^{92}$ The subset of poorly decided CISG cases gets more scholarly criticism, which may be well-intentioned and quite constructive, but those cases may also remain disproportionately prominent in the memories of those considering whether or not to adopt CISG. A converse bias may also be relevant here. Overall, CISG may have become less prominent for many practitioners in countries which have not yet acceded to it, and even those which have. Governmental reports fall back into the bowels of the bureaucracy, UNCITRAL and other organisations promote an ever-growing amount and range of international instruments, and court cases applying CISG to cross-border sales do not expand much in certain jurisdictions. Relatedly, if people come to believe that CISG is not so important, compared to good old national sales law, a "social cascade" to that effect may gather momentum. ${ }^{93}$ Another perverse heuristic may reinforce these problems: the tendency, noted above, to leave "dangers on-screen, benefits off-screen". 94 Such cognitive barriers may also be exacerbated by more emotional reactions, especially if decision-makers are placed under time pressure, ${ }^{95}$ like more and more practitioners nowadays. More emotional factors also seem to explain an observed tendency to ignore probabilities after visualising the worst case outcomes when considering a risk, ${ }^{96}$ such as a case being poorly decided under CISG.

A further psychological phenomenon that seems likely to be reinforcing a bias against full engagement with CISG is the "endowment effect" - the now quite well-documented fact that "people tend to value goods more when they own them than when they do not". A related problem, independent of ownership, is "the status quo bias" - "individuals tend to prefer the present state of the world to alternative states, all other things being equal".97 At first blush, at least in jurisdictions which have acceded to CISG so that it generally provides the set of default rules, such biases would seem to push parties away from deliberately excluding the application of CISG pursuant to article 6.

92 Cass R Sunstein Risk and Reason: Safety, Law and the Environment (Cambridge University Press, Cambridge, 2002) 33.

93 Sunstein, above n 92, 37-39.

94 Sunstein, above n 92, 40; Ewald, above n 85.

95 Sunstein, above n 92, 43-44.

96 Sunstein, above n 92, 45-46.

97 Russell Korobkin "The Endowment Effect and Legal Analysis" (2003) 97 NWUL 1227, 1228. 
However, carefully constructed empirical tests have shown that the baseline established by contractual default rules can be swamped by other reference points, especially clauses established as precedents in standard-form contracts. ${ }^{98}$ Thus, if a practice of excluding CISG evolves - perhaps on the ill-conceived advice of a local practitioner, or because it was forced upon the client by a powerful American trading partner - the status quo bias will make it difficult to reaffirm CISG as the background law. In addition, studies in other areas (like relationships between spouses) suggest that "references for contractual negotiations are likely to be affected by social norms and traditions even when those traditions are not recorded and perpetuated formally". Sophisticated contracting parties or their advisers are more likely to know the applicable default rules and to see them as representing the status quo. But this assumes adequate knowledge and cognitive capacity, which may be undermined by the other biases described.

A related and more longstanding phenomenon identified by psychologists is "cognitive dissonance" - the more a problem becomes evident, the more some people try to ignore it. I suspect this helps explain why Australian and New Zealand private lawyers still tend to downplay EU law developments, for example. English lawyers, even in smaller firms, have come under more direct pressure to overcome initial antipathy about the "irritation" provided by this burgeoning area of law, including unusual concepts like duties of good faith in contract law. ${ }^{99}$ But those in this part of the world, even as they start to learn of EU law's effects on English private law, seem to remain dismissive or nonchalant even as those effects become apparent. Since the developments in EU law and its broader impact on the private law of member states (like Germany) $)^{100}$ are related to CISG, in turn, such cognitive dissonance may also be extended in that direction.

Perhaps these suggestions of psychological obstacles seem far-fetched, despite such perverse heuristics having been shown to operate in many other areas of law, as well as everyday life. Alternatively, or more directly, it could be that Anglo-Australian-New Zealand lawyers are cautious about CISG because of a visceral sense that it incorporates a very different vision of contract law than classical English common law. The latter was reluctant to: (i) find that binding relations had been entered into, (ii) add obligations not sourced in the parties' express agreement, and (iii) allow contractual relations to be altered over time. ${ }^{101}$ As indicated also in Part II and despite the crusade of my former colleague, Professor David McLauchlan, these features persist in important areas of

98 Russell Korobkin "Inertia and Preference in Contract Negotiation: The Psychological Power of Default Rules and Form Terms" (1998) 51 Vand L Rev 1583.

99 Compare Guenter Teubner "Legal Irritants: Good Faith in British Law and how Unifying Law Ends up in New Divergences" (1998) 61 MLR 11; and Luke Nottage "Convergence, Divergence, and the Middle Way in Unifying or Harmonising Private Law" [2004] Annual of German and European Law 166, with for example Campbell and Collins (eds) and Wightman, above n 76.

100 Peter Schlechtriem "EC Directives, Common Principles, and Law Reforms" (2001) 75 Tul L Rev 1177.

101 Form, Substance and Neo-Proceduralism, above n 3, Part II Introduction. 
New Zealand law as well, at least compared to United States and Japanese law. Those include: (i) whether parties should be immediately bound when they have reached agreement in negotiations expressed to be still "subject to contract" or the like, (ii) relief from contractual unfairness, and (iii) frustration of contract due to changed circumstances. ${ }^{102}$ Australian contract law moved away somewhat from this classical model, especially under Chief Justice Mason; but has also seen a swing back, and remains surprisingly firmly within the English law tradition. ${ }^{103}$ Many legal institutions in both Australia and New Zealand still support that tradition, linked to broader patterns of formal legal reasoning at various levels, although ironically those now seem to be unravelling more quickly - or at least more coherently - in England itself due to the infusion of EU law. ${ }^{104}$

Practitioners must be more sensitive to these realities than academics, who do not have to face up to busy (and sometimes grumpy) judges used to the old ways. Practitioners also face vastly more complex factual matrices than academics, who have to rely almost on hearsay - primarily in the form of selected and greatly abbreviated court judgments. So, to simplify, practitioners must develop a keener sense of which "theory of the case" will more likely prevail. In New Zealand and even England, just as was shown empirically in Australia in the early $1990 \mathrm{~s},{ }^{105} \mathrm{I}$ am sure it is still easier for lawyers here to push a more "classical" line in a contract law case than in Japan or even the United States. ${ }^{106}$ Of course, it can often be in the interests of one side's lawyers to argue instead a less classical position, and if that advocate is particularly skilled or lucky - including getting a more adventurous judge in the particular case - he or she may prevail instead. On average, however, one would expect this to happen less frequently. Combined with a stricter doctrine of precedent in Anglo-Australian-New Zealand courts, and the "status quo bias" mentioned above, ${ }^{107}$ there will

102 Compare David McLauchlan "The 'New' Law of Contract in New Zealand" (1992) NZ Recent LR 436 with Form, Substance and Neo-Proceduralism, above n 3, chs 2, 3 and 4.

103 More generally, see Luke Nottage and Takahiro Saito "Nihon no Hoso Yoso Seido Kaikaku e no Teigen Osutorariaho no Shiten Kara [Proposals for Reforming Japan's System for Training Legal Professionals: From the Perspective of Australian Law]" (2004) 62 Horitsu Jiho 30.

104 Compare Form, Substance and Neo-Proceduralism, above n 3, ch 1; and Philip James Giddings and Gavin Drewery Britain in the European Union: Law, Policy and Parliament (Palgrave Macmillan, Basingstoke, 2004).

105 John Gava and Peter Kincaid "Contract and Conventionalism: Professional Attitudes to Changes in Contract Law in Australia" (1996) 10 JCL 141.

106 In addition, it was much easier to persuade Justice Barker (as he then was) that an "entire agreement clause" would be readily enforced under Japanese contract law, because this (more classical) attitude prevails in New Zealand law. See Multiply Ltd v Old Mill Farm Ltd (1995) 7 NZCLC 260, 746 (CA), and Luke Nottage "Contract Law, Theory and Practice in Japan: Plus Ça Change, Plus C'est la Même Chose?" in V Taylor (ed) Asian Laws Through Australian Eyes (Law Book Company, Sydney, 1997) 316. Further, Justice Barker has preferred the stricter approach in other areas of contract law, such as "subject to contract" cases. See, for example, Spengler Management Ltd v Tan [1995] 1 NZLR 120 (HC).

107 Form, Substance and Neo-Proceduralism, above n 3, ch 1; and Korobkin, above n 98. 
probably be even less variability in judicial attitudes. If so, both lawyers and judges from these jurisdictions will also tend to be cautious about the less classical model of contract law presented in CISG, even though the latter remains quite conventional compared to more recent models such as the UNIDROIT Principles of International Contract (UPICC) and the Principles of European Contract Law (PECL). ${ }^{108}$ Thus, although CISG may be much more intelligible to businesspeople even in countries like New Zealand, the lawyers there tend to find it less so, particularly when translating it into the institutional and normative structure of contemporary New Zealand law.

This hypothesis of a "clash of principles" is consistent with much less case law dealing with CISG from the most classical common law jurisdictions like Australia and perhaps especially New Zealand, compared to the case law emanating from the United States. ${ }^{109}$ The latter maintains a more flexible contract law system (at least neo-classical, and sometimes "relational"), despite some assertions of its own "neo-formalist" reaction over the 1990s. ${ }^{110}$ Admittedly, we should also consider more practical aspects explaining this disparity in CISG-related case law. But the hypothesis seems even more sustainable, if it can be proven that Australian and New Zealand parties are regularly excluding CISG. That makes more sense for United States parties, who probably gained further bargaining power over the 1990s given the revival of the United States economy, and thus became more able to obtain their Uniform Commercial Code as the law selected to govern sales contracts. An obvious advantage from that is that the UCC will be more familiar to them - and especially their legal advisers, if a dispute eventuates. ${ }^{111}$ From a doctrinal point of view, commentators have long agreed that the sales law contained in UCC article 2 needs whole-scale improvements. Several advocated reforms drawing on CISG and related international instruments like UPICC, but those largely foundered due to political problems associated with law reform processes in the United States. ${ }^{112}$

108 Richard Hyland "On Setting Forth the Law of Contracts" 40 (1992) Am J Comp Law 541.

109 Compare Monica Kilian "CISG and the Problem with Common Law Jurisdictions" (2001) 10 J Transnat'l L \& Pol'y 217. Apologies to Samual P Huntington The Clash of Civilizations and the Remaking of World Order (Free Press, London, 2000).

110 Compare generally John Esser "Institutionalizing Industry: The Changing Forms of Contract" (1996) 21 Law \& Soc Inquiry 593, with Ralph Mooney "The New Conceptualism in Contract Law" (1995) 74 Oregon L Rev 1131 and Robert A Hillman "The 'New Conservatism' in Contract Law: The Pursuit of Uniformity" (1999) 50 BC L Rev 879. Product liability provides clearer evidence of judicial restraint in another major areas of US private law particularly since the 1990s: see Nottage, above n 89, ch 2.

111 See Susanne Cook "CISG: From the Perspective of the Practitioner" (1998) 17 JL \& Com 343, 349, noting however that the CISG can be a good compromise even for United States negotiating parties.

112 Compare for example Richard Speidel "Revising UCC Article 2: A View from the Trenches" (2001) 52 Hastings LJ 607; with Richard Hyland "Perspectives on Private Law Codification in America in the 21 st Century" ("Legislation in the 21st Century and Private Law" Conference, Tokyo, 12 November 1998) and Alan Schwartz "The Still Questionable Role of Private Legislatures" (2002) 62 La LJ 1147. 
By contrast, if indeed Australian and New Zealand parties are excluding CISG, generally weaker bargaining power makes it less likely that they can obtain their own law as the governing law. Possibly, they may be able to compromise on English law, especially if their trading partners also come from that legal tradition, since this situation would better fit everyone's pre-existing norm structures. Otherwise, however, they will probably have to agree to the national contract law of their trading partners. That might be quite unavoidable in dealing with United States parties, but seems a perverse outcome in other negotiating contexts. Following CISG, or indeed suggesting it as a compromise even if it would not otherwise apply under article 1, would seem a more rational strategy. But the limited numbers of cases applying CISG even in Australia and New Zealand suggest that this tactic is not being pursued. ${ }^{113}$ Japanese companies also do not seem to be trying to opt into CISG. However, that is more understandable given that the country still has not acceded. And a major factor appears to be less involvement still by their legal department staff (let alone outside lawyers) in negotiating and drafting contract documentation, despite steady improvements especially over the 1990 s. ${ }^{114}$

Another more practical consideration that might justify exclusion of CISG also seems to make much less sense at least for Australia and New Zealand. One reason given quite frequently in England for not even adopting the Convention is that it provides a less appropriate regime than the common law in respect of cost, insurance and freight (CIF) export sales, especially of commodities. A primary concern is to ensure parties retain clear rights to terminate, especially when involved in (back-to-back) "string contracts" for commodities. ${ }^{115}$ More generally, as a major provider still of insurance and shipping services, many CIF sales are probably concluded in England or otherwise subjected to its law. To a lesser extent, this may also be true in the United States, which might provide a further more rational explanation for excluding CISG from contracts involving United States parties to which the convention might otherwise apply. It might also play a (minor) role in explaining why certain Japanese companies (including general trading companies dealing in commodities) might be ensuring CISG does not apply. But it seems very unlikely that New Zealand or even Australia experience similarly high proportions of CIF sales. Anyway, there is scope for drafting into CISG-governed CIF contracts some of the purported benefits of the English law

113 Reported cases are a notoriously poor indicator of what happens in "normal" contract negotiations and drafting. At least, we should examine carefully the CISG databases to capture cases in courts in other countries where CISG has been applied when one of the parties (or the product itself) is from Australia or New Zealand. But anecdotal evidence does reinforce the sense that CISG is being readily excluded in our part of the world.

114 Toshimitsu Kitagawa and Luke Nottage "Globalization of Japanese Corporations and the Development of Corporate Legal Departments: Problems and Prospects" in William Alford (ed) Raising the Bar (Harvard University Press, Cambridge, 2005, forthcoming).

115 Takahashi, above $\mathrm{n} 41$, mentions also the speculative nature of commodities trading, and the potential for large losses. Ironically, as he points out, English law itself remains far from clear on many important issues. 
approach. Thus, once again, exclusion of CISG in these two countries seems to involve more of a gut reaction.

Other considerations related to traditional legal reasoning and supporting institutions, especially in Anglo-Commonwealth jurisdictions, probably reinforce this reaction. ${ }^{116}$ These jurisdictions tend to retain a more literal approach to statutory interpretation. ${ }^{117}$ This helps explain why the courts there seem less open, for example, to the invitation in article 7(1) to apply the Convention in an international spirit. The major avenue now would be to draw on the growing quantity and quality of CISG-related case law around the world. But most of that comes from civil law countries, and precedents from those courts seem to have found much less traction even though Australia and New Zealand courts have increased references to judgments from other Anglo-Commonwealth courts. United States courts appear even more parochial, despite an otherwise less strict approach to precedent, and more openness generally to substantive considerations. ${ }^{118}$ Relatedly, AngloCommonwealth countries still seem to prefer "bright-line rules" over broad standards, generating more detailed statutes, a phenomenon also distinguishing the United States. ${ }^{119}$ In short, there is a broader lack of "fit" for CISG linked not just to its underlying principles, ${ }^{120}$ but also to a range of interrelated institutions particularly in countries like Australia and New Zealand. Potentially, there should be a better fit in the United States, and especially Japan. ${ }^{121}$ Impediments to full engagement in those countries seem more directly pragmatic, such as business and organisational considerations when negotiating cross-border contracts.

On the other hand, even in Anglo-Commonwealth jurisdictions there have been signs of a move away from classical contract law thinking. More importantly in the short-term, because it helps elaborate a denser doctrinal system, the infrastructure supporting CISG has grown enormously particularly since the late 1990 s. Commentaries no longer focus on its legislative history - itself still

116 Form, Substance and Neo-Proceduralism, above n 3, ch 1.

117 Compare D Neil MacCormick and Robert S Summers (eds) Interpreting Statutes: A Comparative Study (Dartmouth, Aldershot, 1997); with Rick Bigwood (ed) Legal Method in New Zealand: Essays and Commentaries (Butterworths, Wellington, 2001)

118 Compare MacCormick and Summers, above n 117; with Bigwood, above n 117; and Volkmar Gessner (ed) Foreign Courts: Civil Litigation in Foreign Legal Cultures (Oñati International Series in Law and Society, Dartmouth, 1996).

119 Compare Robert Cooter and Thomas Ginsburg "Comparative Judicial Discretion: An Empirical Test of Economic Models" (1996) 16 Int'l Rev L \& Econ 295; and Robert Cooter and Thomas Ginsburg Leximetrics: Why the Same Laws Are Longer in Some Countries Than Others (Law \& Economics Research Paper No LE03-012, University of Illinois, 2004).

120 Compare Ronald Dworkin Law's Empire (Fontana, London, 1986).

121 For example, Japan has long been more comfortable with more broadly stated legislation. Hence, scholarship examining principles of statutory interpretation such as "literal interpretation" is a comparatively recent phenomenon. 
a bone of contention in Anglo-American law - and conflicting academic theories. They must and do engage with the growing volume of case law. ${ }^{122}$ Overall, decisions by courts - let alone arbitral tribunals - do not show too much of a "homeward trend", namely interpretation clearly favouring reasoning based on local (pre-CISG) sales law. ${ }^{123}$ The case law on CISG has also became vastly more accessible when UNCITRAL put its CLOUT service online, and Pace University inaugurated its own database adding extensive original and reproduced secondary literature - the value-added "legal information engineering" so essential to contemporary legal practice. ${ }^{124}$ That university was also central in unveiling recently an international Advisory Council on CISG, including my former colleague in Japan, Professor Hiroo Sono. The Council presented a commissioned report to the International Chamber of Commerce (ICC) in 2003 regarding electronic transactions in the context of the Convention, and has published two further commentaries on more specific articles. ${ }^{125}$ Even more so than other emerging global standards, like the 1985 EC Directive on Product Liability, ${ }^{126}$ combining such material emanating from different parts of the world helps greatly in filling in the gaps.

Further elaboration can be gained by comparing other initiatives that have drawn on CISG provisions or principles. The most well known are UPICC and PECL, ${ }^{127}$ but CISG has also

122 Compare the successive editions culminating in Honnold, above n 10; Schlechtriem, above n 73; Schmidt, above $\mathrm{n} 5$. Even introductions to CISG are now beginning to engage with the case law. See for example Michael Bridge The International Sale of Goods: Law and Practice (Oxford University Press, Oxford, 1999).

123 See Larry DiMatteo and others "The Interpretive Turn in International Sales Law: An Analysis of Fifteen Years of CISG Jurisprudence" (2004) 24 Nw J Int'l L \& Bus 299. Of course, there are exceptions, with Anglo-American courts coming in for considerable criticism. See for example Monica Kilian "CISG and the Problem with Common Law Jurisdictions" (2001) 10 J Transnat'1 L \& Pol'y 217; and Bruno Zeller's persistent critique of Australian case law, Victoria University Faculty of Business and Law $<$ http://www.business.vu.edu.au> (last accessed 18 June 2005).

124 Richard E Susskind Transforming the Law: Essays on Technology, Justice, and the Legal Market Place (Oxford University Press, Oxford, 2000).

125 Albert Kritzer and Loukas A Mistelis "CISG-AC Publishes First Opinion" (2003) 15 Pace International Law Reveiw 453; CISG Advisery Council "Examination of the Goods and Notice of Non-Conformity: Articles 38 and 39" CISG-AC Opinion 2 <www.cisg.law.pace.edu> (last accessed 18 June 2005); CISG Advisery Council "Contracts for the Sale of Goods to be Manufactured or Produced and Mixed Contracts (Article 3 CISG)" CISG-AC Opinion 4 <www.cisg.law.pace.edu> (last accessed 18 June 2005).

126 Nottage, above n 89, especially ch 3 (combining otherwise quite limited case law especially from the European Court of Justice, England, Australia, Japan; and comparing this especially with the case law trends in the United States).

127 See especially the useful "match-up" of both with the (further annotated) text of CISG on the Pace University website <www.law.pace.edu $>$ (last accessed 18 June 2005); and the table (in Japanese) compiled by Professor Shigeru Kagayama, <www.nomolog.nagoya-u.ac> (last accessed 19 September 2005) 
influenced reforms to the law of obligations in Germany, for example. ${ }^{128}$ No doubt such developments will carry through to the contract law harmonisation initiatives picking up pace in the EU. "Reverse engineering" from such developments, especially from a global perspective, can also teach us much about what CISG is and what it can grow into.

Most importantly, this lingua franca - much more than the "esperanto" denigrated by one prominent English judge! ${ }^{129}$ - is also becoming more consistently understandable to a new generation of lawyers on a global scale. A major development, with few parallels in other areas where harmonisation of commercial law has been initiated, is the Vis Arbitral Moot Competition. Already by the late $1990 \mathrm{~s}$, it was attracting hundreds of students, academics, and practitioners to Vienna the week before Easter, to argue cases especially applying CISG in a mock arbitral setting. This was one area of CISG-related activity in which Australia was an active player from early on, thanks to some rather entrepreneurial (and successful) universities, but VUW has led a charge from New Zealand too, and some interest has even been created from Japan. ${ }^{130}$ The experience is so educational, in so many ways, that the large group of Vis Moot alumni is probably already growing into a major force for consistent yet creative engagement with CISG in cross-border commercial practice. $^{131}$

128 See Schlechtriem, above $\mathrm{n} 73$.

129 John Hobhouse "International Conventions and Commercial Law: The Pursit of Uniformity" (1990) 106 LQR 530. Another judge then sitting in the House of Lords, Lord Steyn (see for example Johan Steyn "The Intractable Problem of the Interpretation of Legal Texts" (2003) 25 Sydney LR 5), emerged instead as a fan of CISG, but seemingly for instrumental reasons (developing a new market for English legal service providers) rather than a strong preference for its underlying legal principles. Compare also Barry Nicholas "The United Kingdom and the Vienna Sales Convention: Another Case of Splendid Isolation?" (1993) Centro di Studi e Richerche di Diritto Comparato Straniero <http://soi.cnr.it> (last accessed 19 June 2005).

130 Luke Nottage "Practical and Theoretical Implications of the Lex Mercatoria for Japan: CENTRAL's Empirical Study on the Use of Transnational Law" (2000) 4 Vindobona Journal of International Commercial Law and Arbitration 132, with statistics; Luke Nottage "Educating Transnational Commercial Lawyers for the $21^{\text {st }}$ Century: Towards the Vis Arbitral Moot in 2000 and Beyond" (1999) 66 Hosei Kenkyu F1 [Educating]. Of course, the Jessup Moot provided a sort of precedent in public international law (see International Law Students Association <http://www.ilsa.org > (last accessed 18 June 2004)), and there are now popular moots in EU law (see European Law Moot Court Competition $<$ http://www.elmc.org $>$ (last accessed 18 June 2005)), WTO law (see European Law Students' Association $<$ http://www.elsa.org $>$ (last accessed 18 June 2005)), and even Space Law (see Manfred Lachs Space Law Moot Court Competition $<$ http://www.spacemoot.org $>$ (last accessed 18 June 2005)) and the UPICC Intercollegiate Negotiation Competition <http://www2.osipp.osaka-u.ac.jp> (last accessed 18 June 2005)). But the sheer scale of the Vis Moots (see Pace University School of Law <www.cisg.law.pace.edu> (last accessed 18 June 2005)), since 1994 , is phenomenal.

131 See the website of the Moot Alumni Association (MAA) <http://www.maa.net/> (last accessed 18 June 2005), which now comprises around 850 members, including over one hundred in Australia but only nine in each of New Zealand and Japan). The MAA also publishes the Vindobona Journal of International Commercial Law and Arbitration, for example, and has observer status at UNCITRAL deliberations. 
In short, even CISG's putative advantages of accessibility, intelligibility, and consistency may not be so obvious to lawyers, as opposed to businesspeople. Nevertheless, already and especially given present trajectories, these advantages do come out ahead. If CISG is indeed being excluded, by legal advisers in countries like Australia and New Zealand, and the mother country still refuses to accede to the Convention, then advisers and law reformers should reflect more on psychological blocks which seem to be contributing to this situation. With a renewed dose of realism, scepticism about CISG seems increasingly dubious.

\section{BEYOND BIAS AND INERTIA}

Law reformers should find it easiest to minimise perverse cognitive biases and more emotional reactions. They can and should include more experts, be under less time pressure, and have more opportunities for structured deliberation with a broader group of people. In addition, they should be less open to pressure from interest groups, particularly those reactionary legal professionals eager to preserve the mysterious edifice of national sales law. On a more objective assessment of costs versus benefits, the case for countries such as Japan to accede to CISG now seems quite straightforward, especially as parties remain free to exclude its operation (wholly or just in part) in particular categories of cases. That leaves the possibility of retaining stricter English sales law for such cases, if that is what is really desired by the particular subset of companies arguing cases before English courts or arbitrators. But expertise can also be built up and applied in CISG cases for other types of contracts, which are being lost to other increasingly popular venues for cross-border contract dispute resolution, such as the ICC (based in Paris), the American Arbitration Association (AAA), and even emerging arbitral venues in the Asia-Pacific. ${ }^{132}$ Through engagement with CISG, English practitioners can still work to guide it in a more classical direction, for example by allowing for good faith to be admitted as a guiding principle but giving it a narrow interpretation. ${ }^{133}$ Yet CISG can also become a further bridge to engagement with (generally more substantive reasoning based) EU law. Also, if accession to CISG is sustainable for England, it must hold all the more so for Japan, whose legal system does not attract the world-wide business of English courts and arbitrators for some types of cases, and whose contract law remains more open to substantive reasoning. As in many other countries, Japan may find it difficult to find parliamentary time to consider and adopt CISG. But its legislation-generating processes have become more diverse particularly since the mid-1990s, and larger law reform projects more pressing for its stagnant economy have now largely been completed. ${ }^{134}$

132 See comparative statistics at Hong Kong International Arbitration Centre $<$ http://www.hkiac.orghtml $>$ (last accessed 18 June 2005).

133 Compare for example Elisabeth Peden "The Meaning of Contractural Good Faith"' (2002) 22 ABR 235.

134 See for example Nottage and Wolff, above n 87; Luke Nottage "Civil Procedure Reforms in Japan: The Latest Round" (2005) 22 Ritsumeikan Law Review 81. Increasing numbers of Members' Bills have been submitted to Parliament, although not many are adopted, so that route (used to enact New Zealand's 
Law reformers in countries that have already acceded to CISG should also remain more active in promoting it. The New Zealand Law Commission has been better than its Australian counterparts in following up earlier initiatives in other areas of international trade law, such as arbitration legislation. However, there remain risks of "missing the bigger picture", especially by focusing on local case law as a guide to further possible reform. ${ }^{135}$ Still, a follow-up report on CISG would help bring it into the limelight again. It could review promising case law developments world-wide as well as more problematic decisions, and offer drafting suggestions to get around the latter or to apply in certain types of cases (like CIF commodity sales).

Law reformers at the transnational level should also boost their engagement with CISG. Primary responsibility lies with UNCITRAL. It missed an opportunity to take up Professor John Murray's suggestion of developing "Official Comments" to CISG, paralleling the UCC process, ${ }^{136}$ although UNCITRAL's case law Digest combined with reports of the Advisory Council centred on Pace University may begin to fill this void. UNCITRAL also should not be afraid at least to raise the possibility of a protocol to CISG, or even a model law on international sales (which might also be extended to domestic sales), and to form a working group to consider other possible improvements to the Convention, as it has done since 2000 in the area of international commercial arbitration. But we should also not forget the possibility of advancing business law harmonisation initiatives like CISG at a regional level. The Asia-Pacific Economic Cooperation (APEC) forum seems to be losing momentum, focusing increasingly on security and diplomatic issues. But many bilateral free trade agreements are being concluded by Australia, New Zealand and now Japan, including several countries (like Singapore) who have acceded to CISG. More tailored obligations and institutions could be superimposed on such free trade associations to take harmonisation to new levels. ${ }^{137}$

However, legal practitioners face the greatest responsibility and challenges, particularly in overcoming psychological barriers to CISG. Problems will tend to be most acute for those in sole practice, due to less opportunity to reflect with others on possible perverse heuristics; and especially for barristers or others specialising in court work, who also tend to cover many areas of law and therefore have less incentive to invest in new knowledge about CISG. ${ }^{138}$ This background feeds into several problematic cases that have been litigated so far in Australian courts. However, some

Arbitration Act 1996) might be an option for Japan. More conventionally, adopting CISG could be advanced by the Legislative Reform Council, which has been reformed to involve new members or more project-based committees with a view to enacting private law legislation more quickly.

135 Luke Nottage "Reviewing the Arbitration Act 1996" [2003] NZLJ 34.

136 John E Murray "The Neglect of the CISG: A Workable Solution" (1998) 17 JL \& Com 374-379.

137 Compare more generally Luke Nottage "Redirecting Japan's Multi-Level Governance" in Klaus Hopt et al (eds), Corporate Governance in Context: Corporations, State and Markets in Europe, Japan and the US (Oxford University Press, Oxford, 2005) 571.

138 Compare Korobkin, above n 97 and 98. 
specific criticisms seem over-stated or misguided, with advocates and judges trying quite hard to make sense of CISG - albeit sometimes still too much through the lens of the Anglo-Australian approach to sales law. ${ }^{139}$ Harping on about the more problematic cases or aspects risks reinforcing an adverse availability heuristic or other biases identified in Part III above.

Barristers and litigators also depend on back-up from firms including solicitors, also involved in planning transactions such as international sales. Firms should have more scope to develop less biased decision-making, but need to construct and police processes to minimise the risk of "cascades" or increasing polarisation as initial views emerge in a group context. ${ }^{140}$ Even bigger law firms need to be careful, as they hire outside consultants (like academics) on a continuous but parttime basis. Even those individuals may prefer the (national sales) law they remain more familiar with. If they have developed biases against CISG, especially at an earlier stage of its existence, they can be carried over into the law firm environment, and quite easily entrenched, given these individuals' role precisely as the experts in cutting-edge legal developments. This can appear in the form of adverse internal memoranda or in-house seminar presentations, or clauses inserted in standard-form contracts excluding some or all of CISG, which later develop a life of their own and become very hard to adjust. Overall, however, we can expect - and already witness in Australia attempts by some larger or more specialist firms instead to develop and promote strategic awareness of CISG. ${ }^{141}$

Advisers in corporate legal departments may offer the most hope for more balanced assessments, given their numbers, and proximity to the normative expectations of their business department colleagues - closer to the general principles underlying CISG than to those that have traditionally dominated sales law in the English tradition. However, if those colleagues buckle easily to pressure to exclude CISG in favour of the UCC in order to secure a deal with an American party, for example, the in-house lawyers have to be capable of explaining the risks and pursuing other alternatives. Japanese corporate legal department staff seem less willing and able to do this, despite growing resources and status since the 1990 s, although comparative empirical data is sparse. ${ }^{142}$

Responsibility for approaching CISG more effectively lies with educators too. ${ }^{143}$ Thought must also be given to minimising psychological barriers. This means, for example, treading a fine line in

139 Compare Bruno Zeller, Victoria University Faculty of Business and Law $<$ http://www.business.vu.edu.au $>$ (last accessed 18 June 2005), with the more balanced critique by Lubbe, above $n 5$.

140 Compare Sunstein, above n 92.

141 See for example Gehle, above $\mathrm{n}$ 8. The author also related to me that his firm has had the experience of agreeing to exclude CISG, but for example in a deal involving a much smaller Tasmanian law firm on the other side.

142 Kitagawa and Nottage, above n 114.

143 See also for example William Dodge "Teaching the CISG in Contracts" (2000) 50 J Legal Educ 72. 
analysing CISG. The analysis must be sufficient to keep it "on screen", but not be so critical as to over-state risks involved in engaging with CISG. Educators must also be creative in finding ways to explain CISG's underlying principles, not just rules, in ways that fit as closely as possible with evolving normative and institutional structures in domestic law, even in Anglo-Commonwealth jurisdictions oriented towards more formal reasoning.

Such education is probably easier at the postgraduate level, or in continuing legal education seminars (also or instead through law societies). Leading Australian universities enjoy more elaborate programs than New Zealand counterparts, with an LLM or a specialist Masters degree in Law now widely accepted as helping early- and mid-career advancement in a range of law-related jobs. In the early 1990s, Japan also tried specialist LLM courses aimed at those with prior work experience. But the universities who received funding tended to be "the usual suspects", and there were insufficient incentives to hire new staff or to develop and maintain innovative programs, so this initiative lost momentum. More radically, 68 universities were allowed to inaugurate larger postgraduate "law schools" from April 2004; and at least 20 per cent of teaching staff were required to have at least 10 years' experience in practice, generating a wave of moves into and among universities. Still, the National Legal Examination - which must be passed to become a lawyer, judge or prosecutor - remains very difficult, and focused on the "Six Codes" (roppo) such as the Civil Code. ${ }^{144}$ Unless the new law schools can wrest control over entry into the profession away from the Supreme Court of Japan, the Ministry of Justice, and the bar associations, the prospects for more education about CISG remain quite limited at this level. Courses will continue to be offered particularly in the Graduate Schools of Law, but those are still aimed at those interested in more academic research or careers.

Teaching more (and better) CISG at undergraduate level is another important task, but not easy. The most common option would be as a portion of a course in international commercial law, like one I have developed at the University of Sydney from 2002. But it is difficult to justify focusing too much on CISG itself, if the pedagogical objectives are both practical (learning how to plan and execute cross-border commercial transactions) and theoretical (how legal systems interact at various levels to promote cross-border trade). The need for broader coverage will become especially acute for smaller universities. Even broader courses there will tend to have fewer senior students interested in or able to take such courses, and the courses must leverage off more basic (national) contract law teaching and learning. On the other hand, there may be more potential for teaching CISG at undergraduate level than, say, international commercial arbitration. ${ }^{145}$

144 Luke Nottage "Build Postgraduate Law Schools in Kyoto and Will They Come - Sooner and Later?" (2005) 7 Australian Journal of Asian Law (forthcoming).

145 Luke Nottage Teaching Arbitration in Australia: Towards Transnational Associations (CDAMS Discussion Paper 04-30, 2004) Center for Legal Dynamics of Advanced Market Societies <www.cdams.kobe-u.ac.jp> (last accessed 9 November 2005). 
Instructors need to back up their teaching with cutting-edge research. This helps attract and keep ahead of bright students, to continue improving curriculum design and delivery, and allows publication of research that can reach out to a broader audience. Conferences like this one are also a crucial part of that agenda. Japan has consistently engaged in such events, and produced some very fine scholarship on CISG. But much of the research is still rather one-way, reflecting a longerstanding pattern of foreign law studies in Japan, as well as the practical reality that CISG is still not really part of Japanese law. ${ }^{146}$ That also means that the writings tend not to find their way into more practitioner-oriented law journals, with high circulation also among other academics. My impression is that Australian and New Zealand journals also have many fewer articles on CISG, adjusted for population (generally, and especially among jurists and law students), compared even to the United States for example. This exacerbates a vicious circle of either neglect or virulent critique. ${ }^{147}$ Accessibility has also been a problem, although more Australian and New Zealand journals have come online via the internet or even onto databases like Lexis.

Overall, then, critical mass still needs to be developed at many levels to secure more sustainable engagement with CISG. This is particularly true in countries like Japan and England, where CISG still needs to get properly onto the legislative agenda. But it is also a challenge for member states like New Zealand and Australia, where law reformers, legal academics, and especially legal practitioners share responsibility in thinking through more carefully how to maximise the potential of this harmonisation measure. The more people get involved and informed, in more coherent processes of interaction, the more chance we may have of overcoming psychological impediments as well as institutional barriers.

A broader implication of this analysis, therefore, is that globalisation of law does not happen by itself. Many contemporary legal theorists have identified the potential for steps to falter on the path towards convergence on new global standards, albeit for a variety of reasons. Some well-known ones include the self-referentiality or "autopoiesis" of pre-existing social subsystems (including law), path-dependence, dialectics of contemporary democratic processes, and idiosyncracies due to micro-level power struggles reflecting broader tensions in globalisation. ${ }^{148}$ Some of the

146 Article 1(1)(b) of CISG opens the way to a Japanese court to apply CISG, but so far none has. One opportunity was clearly missed: see Nottage, "Educating", above n 130. By contrast, in more recent obiter dicta, the Tokyo District Court indicated some willingness to identify CISG as applicable pursuant to article 1(1)(b) even though the United States has made an article 95 reservation. See Nippon Systemware Kabushikigaisha v O, CISG Case Presentation <http://cisgw3.law.pace.edu> (last accessed 18 June 2005).

147 Journals specialising in international and comparative law have emerged much more slowly even in Australia. Meanwhile - and anyway, to maximise readership - special issues of university or commercially published journals should be encouraged.

148 See, respectively, for example Teubner, above n 99, Jeffery N Gordon and Mark J Roe Convergence and Persistence in Corporate Governance (Cambridge University Press, New York, 2004), Juergen Habermas Between Facts and Norms (MIT Press, Cambridge, 1996), and Yves Dezalay and Garth G Bryant Global Importation of a New Legal Orthodoxy (University of Michigan Press, Ann Arbor, 2002). The foundational 
psychological hurdles outlined in this paper further complicate the picture, and the prognosis. But we have to be realistic about the trajectory of globalisation, to see how it may be distorted, and put back on track if the advantages seem to outweigh the disadvantages - as they seem to for CISG. "Regionalisation", with the Convention finding ample traction in civil law jurisdictions like Germany but much less in the Anglo-American law world, is not too surprising but still represents a missed opportunity for more thorough-going harmonisation at multiple levels. Trying instead to substitute and then promote UPICC seems unlikely to resolve the main problems raised, ${ }^{149}$ especially psychological barriers. Growing diversity in harmonisation instruments is the trend of the times, and is to be welcomed. But this need not mean throwing the baby out with the bathwater, especially as CISG remains so central to understanding other sets of norms like UPICC. Both hard and soft law create the richness of the new lex mercatoria, even more obviously than the interaction of formal and informal processes in domestic law. 150

ideas of Teubner and Habermas are set out and applied in Form, Substance and Neo-Proceduralism, above n 3, ch 5. For other attempts to locate CISG in broader theoretical debates, see for example Anthony S Winer "The CISG Convention and Thomas Franck's Theory of Legitimacy" (1998) 19 Nw J Int'l L \& Bus 1, and Paul Stephan "The Futility of Unification and Harmonization in International Commercial Law" (1999) 39 Va J Int'l L 743.

149 Compare Kilian, above n 109.

150 See also Luke Nottage The Procedural Lex Mercatoria: The Past, Present and Future of International Commercial Arbitration (CDAMS Discussion Paper, 2003) Center for Legal Dynamics of Advanced Market Societies < www.cdams.kobe> (last accessed 18 June 2005). 
